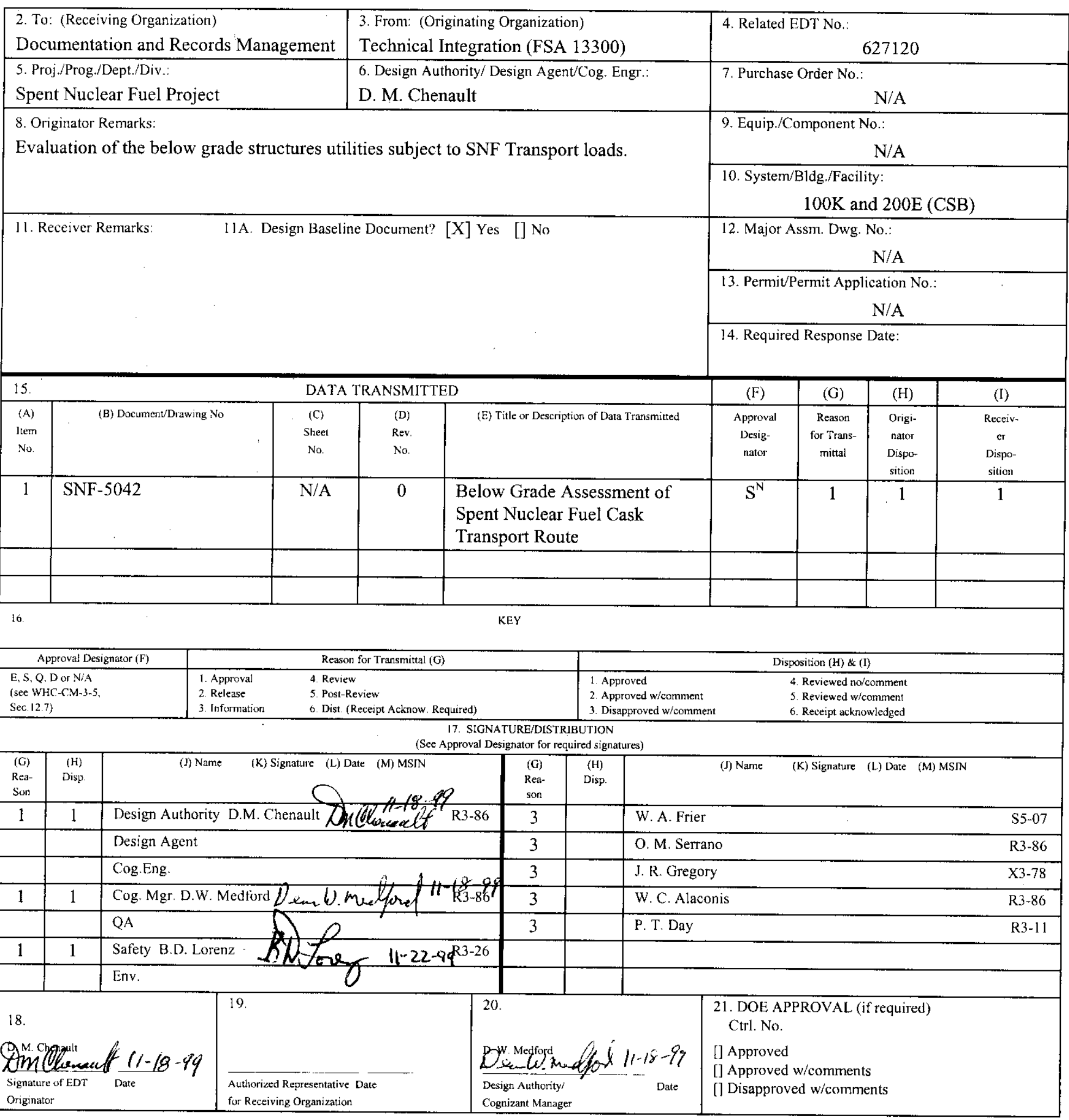




\title{
BELOW GRADE ASSESSMENT OF SPENT NUCLEAR FUEL CASK TRANSPORT ROUTE
}

\author{
DM Chenault \\ Fluor Daniel Hanford \\ P.O. Box 1000 \\ Richland, WA 99352 \\ U.S. Department of Energy Contract DE-AC06-96RL13200 \\ $\begin{array}{ll}\text { EDT/ECN: } & 627120 \\ \text { Org Code: } & \text { FSA } 13300 \\ \text { B\&R Code: } & \text { EW7040000 }\end{array}$ \\ UC: 600 \\ Charge Code: 105528 \\ Total Pages: 25
}

Key Words: SNE, transport, grade, cross-tie, tunnel, utilities

\begin{abstract}
:
The report provides an assessment of the route for the SNF Fuel transport system from the $\mathrm{K}$ Basins to the CVDF and to the CSB. Results include the identification of any underground structures or utilities traveled over by the transport, the overburden depths for all locations identified, evaluation of the loading conditions, and determination of the effects of the loads on the structures and utilities.
\end{abstract}

TRADEMARK DISCLAIMER. Reference herein to any specific commercial product, process, or service by trade name, trademark, manufacturer, or otherwise, does not necessarily constitute or imply its endorsement, recommendation, or favoring by the United States Government or any agency thereof or its contractors or subcontractors.

Printed in the United States of America. To obtain copies of this document, contact: Document Control Services, P.O. Box 950, Mailstop H6-08, Richland WA 99352, Phone (509) 372-2420; Fax (509) 376-4989.

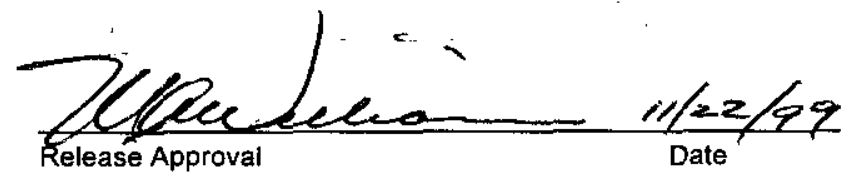

Release Approval

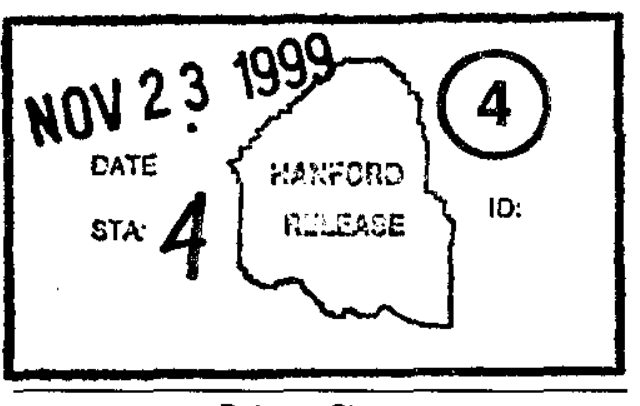

Release Stamp 


\section{BELOW GRADE ASSESSMENT OF SPENT NUCLEAR FUEL CASK TRANSPORT ROUTE}

Prepared for

\section{FLUOR DANIEL HANFORD}

Contract No. 263 - Release 47

November 1999

Prepared by: C. M. Conselman Reviewed by: Date: $11 / 11 / 99$ 
SNF-5042

REVISION 0

\section{TABLE OF CONTENTS}

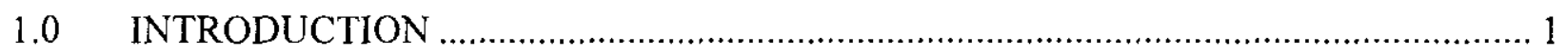

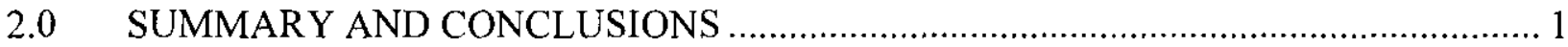

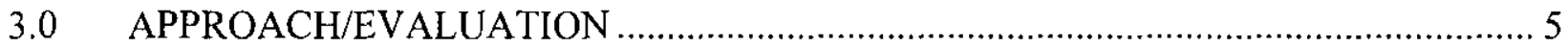

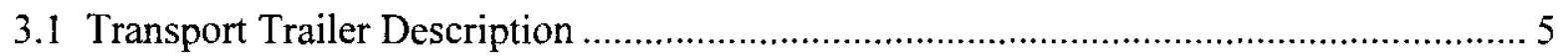

3.2 Routing, Access Control, and Speed Limitations....................................................... 7

3.3 Identification of Underground Structures and Utilities ................................................. 7

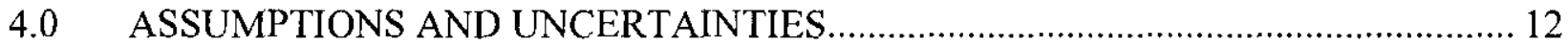

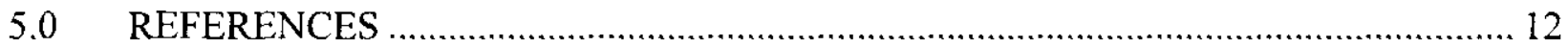

\section{APPENDICES}

Appendix A

ARES Corporation Calculation No. 9904500.47-001, Revision 0 
SNF-5042

REVISION 0

TABLES

Table 2.1. Identification of Underground Structures and Utilities 2

Table 3.1. Road Surface Conditions and Cross-Sections for the SNF Transport Route 7

\section{FIGURES}

Figure 3.1 SNF Transport Trailer

Figure 3.2. SNF Cask Transport Route............................................................................... 8

Figure 3.3. SNF Cask Transport Route (100 K Area) .......................................................... 9

Figure 3.4. SNF Cask Transport Route (CSB) ............................................................. 10 
SNF-5042

REVISION 0

\section{ACRONYIMS}

$\begin{array}{ll}\text { AEC } & \text { Atomic Energy Commission } \\ \text { CSB } & \text { Canister Storage Building } \\ \text { CTS } & \text { Cask Transportation System } \\ \text { CVDF } & \text { Cold Vacuum Drying Facility } \\ \text { GAWR } & \text { Gross Axle Weight Rating } \\ \text { GVWR } & \text { Gross Vehicle Weight Rating } \\ \text { KE } & \text { K-East } \\ \text { KW } & \text { K-West } \\ \text { SNF } & \text { Spent Nuclear Fuel }\end{array}$


SNF-5042

REVISION 0

\section{BELOW GRADE ASSESSMENT OF SPENT NUCLEAR FUEL CASK TRANSPORT ROUTE}

\subsection{INTRODUCTION}

The purpose of this report is to provide an assessment of the route for the Spent Nuclear Fuel (SNF) Cask Transportation System (CTS) transport trailer from the storage basins in the $100 \mathrm{~K}$ Area [105-K-East $(\mathrm{KE})$ and $105-\mathrm{K}$-West $(\mathrm{KW})]$ to the Cold Vacuum Drying Facility (CVDF), and then to the Canister Storage Building (CSB) in the 200 East Area. This includes identifying any underground structures or utilities that will be traversed, determining the soil overburden depths for all locations identified, evaluating the loading conditions at each location, and determining if the transport trailer will have any adverse impact on any of the structures or utilities.

\subsection{SUMMARY AND CONCLUSIONS}

It usually is not necessary to consider the effect of live loads on buried utilities except where they are exceedingly large or where they occur on objects with very little cover. As can be seen by examining Table 2.1, the highest percentage of the transport trailer live loads transmitted to any identified buried utility is 3 percent. This is an insignificant amount of loading when compared to the soil dead load, with the exception of locations $16,17,18,24$, and 25. The live load at these locations varies between 10 and 109 percent of the dead load, but the total loading is still relatively low. Combined with the fact that all of the utilities have been subjected to various vehicle live loads over time, this indicates that the transport trailer loads should have no adverse impact on them.

Due to their importance and configuration, additional evaluation was performed on the two tunnel crossings (locations 3 and 5). The 105-KW to $165-\mathrm{KW}$ tunnel (location 3 ) was designed for a crane loading of 204 kips (AEC 195 - Atomic Energy Commission). The crane loads were applied using three different configurations running along the tunnel and were calculated to have an applied load of 14.6 kips per foot. This loading condition is greater than the loading condition applied by the transporter. Therefore, it can be concluded that the tunnel is structurally adequate to withstand the transport trailer loading conditions.

The KE to KW cross-tie tunnel (location 5) was evaluated for various crane loadings in Structural Evaluation for the $165 \mathrm{~K}$ Cross-Tie Tunnel, $100 \mathrm{~K}$ Area, WHC-SD-SNF-FLE-001, Revision 0 (Islam 1995). This document concluded that the tunnel was structurally adequate to 


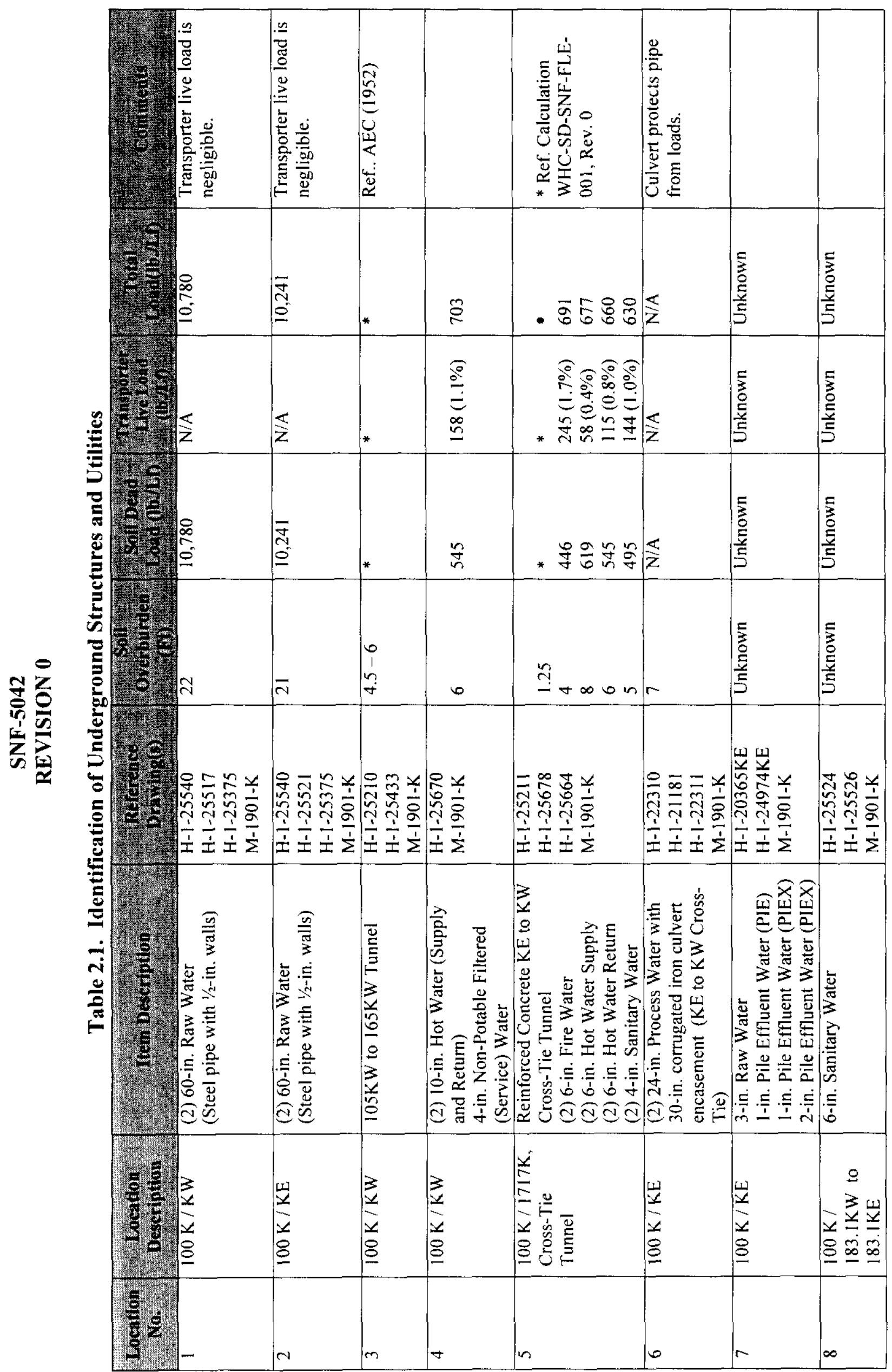




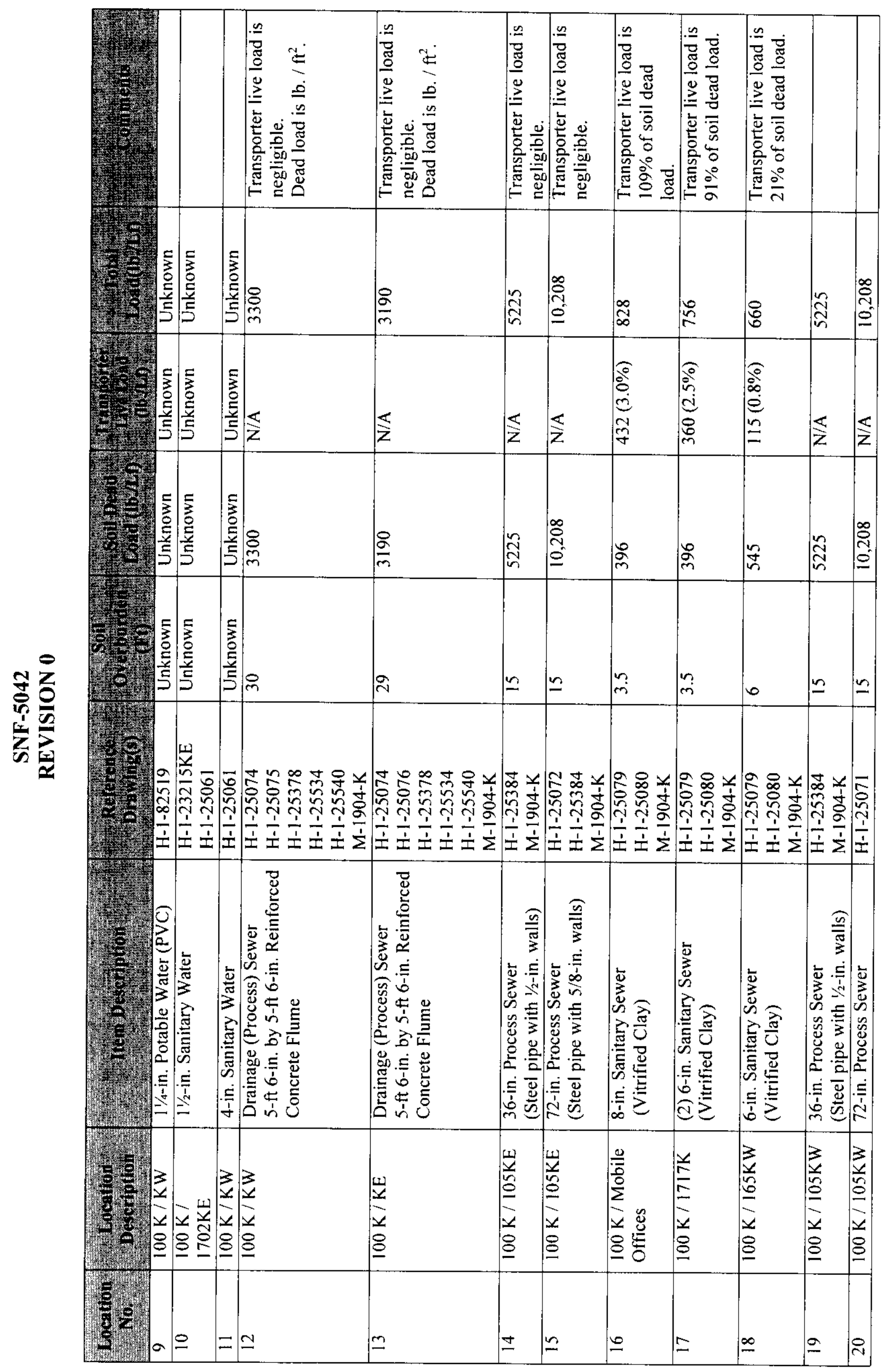




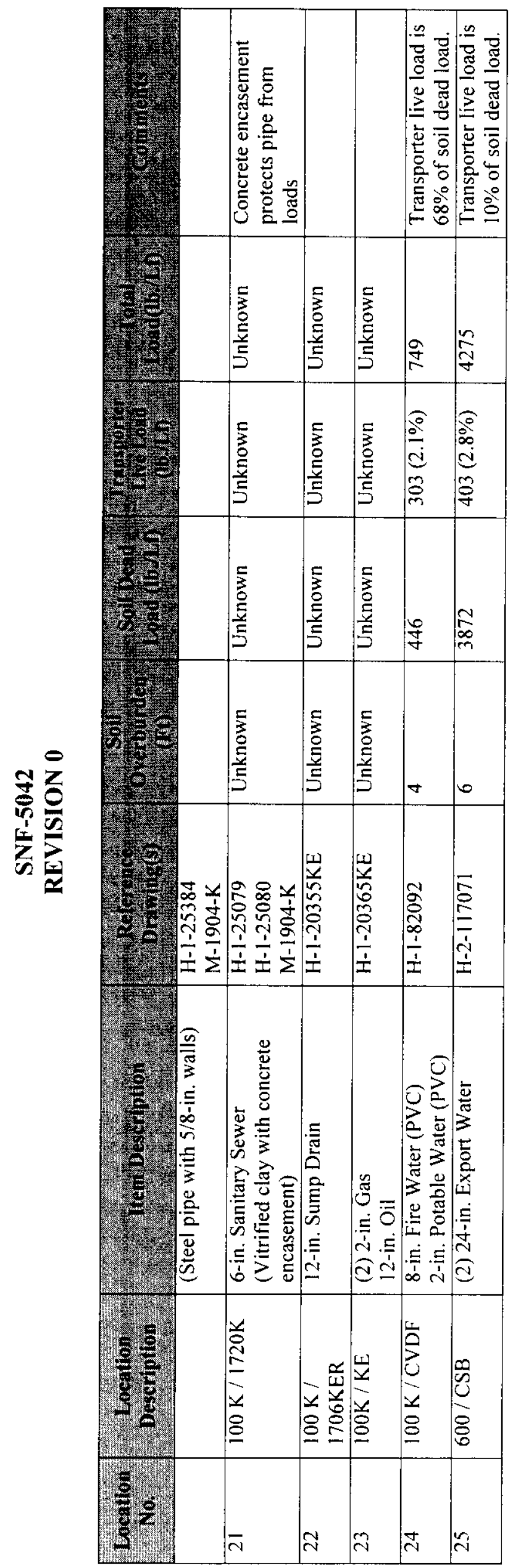




\section{SNF-5042 \\ REVISION 0}

withstand the crane loading conditions, which had uniform applied wheel pressures between 35 psi and 45.5 psi. The applied uniform wheel pressure calculated for the transport trailer is $70 \mathrm{psi}$.

When comparing the transport trailer loading conditions to the previously evaluated crane loadings using applied wheel pressures, it could not directly be concluded that the tunnel is structurally adequate to withstand the transport trailer loading conditions. Therefore, this tunnel has been evaluated in more detail to determine if it can withstand the loads imposed on it by the transport trailer. This evaluation, which is included as Appendix A, concludes that the KE to $\mathrm{KW}$ crosstie tunnel is structurally adequate to withstand the transport trailer loads.

The results of this evaluation indicate that the CTS transport trailer will not have any notable affect on any of the underground structures or utilities that it traverses. It is recommended, however, that the road surfaces within the $100 \mathrm{~K}$ Area be treated (cracks sealed, potholes repaired, etc...) prior to use of the CTS.

The section of road between Route $4 \mathrm{~S}$ and the CSB was not evaluated since this road is relatively new and was built to more current Washington State Department of Transportation and American Association of State Highway and Transportation Officials standards, and the transport trailer live loads fall within the loading conditions used by those standards.

\subsection{APPROACH/EVALUATION}

In order to evaluate the loading conditions at each of the identified locations, several factors were considered. The evaluations for each of the locations are presented in the following sections. These evaluations include a description of the transport trailer (including wheel loads), a discussion and brief evaluation of the transport route, identification of the underground structures and utilities that will be traversed, and determining the soil overburden depths for the locations identified.

\subsection{Transport Trailer Description}

The transport trailer is designed to the criteria specified in WHC-S-0396, Revision 1, Specification for SNF Path Forward Cask and Transportation System (Kee 1995). It consists of a tri-axle semi-trailer provided by TransNuclear Inc. and Nelson Manufacturing Company. The trailer will be attached to a standard Hanford Site tractor. The transport trailer loaded with the Multi-Canister Overpack/cask is shown in Figure 3.1. The following information was taken from the identification plate of one of the transport trailers:

$\begin{array}{ll}\text { Model } & \text { ARTA-35LD } \\ \text { GAWR } & 20,280 \mathrm{lb} . \\ \text { GVWR } & 97,280 \mathrm{lb} . \\ \text { Rims } & 8.25 \times 22.5 \\ \text { Tires } & 275 / 70 \mathrm{R} \times 22.5 @ 115 \mathrm{psi} \text { (cold) }\end{array}$




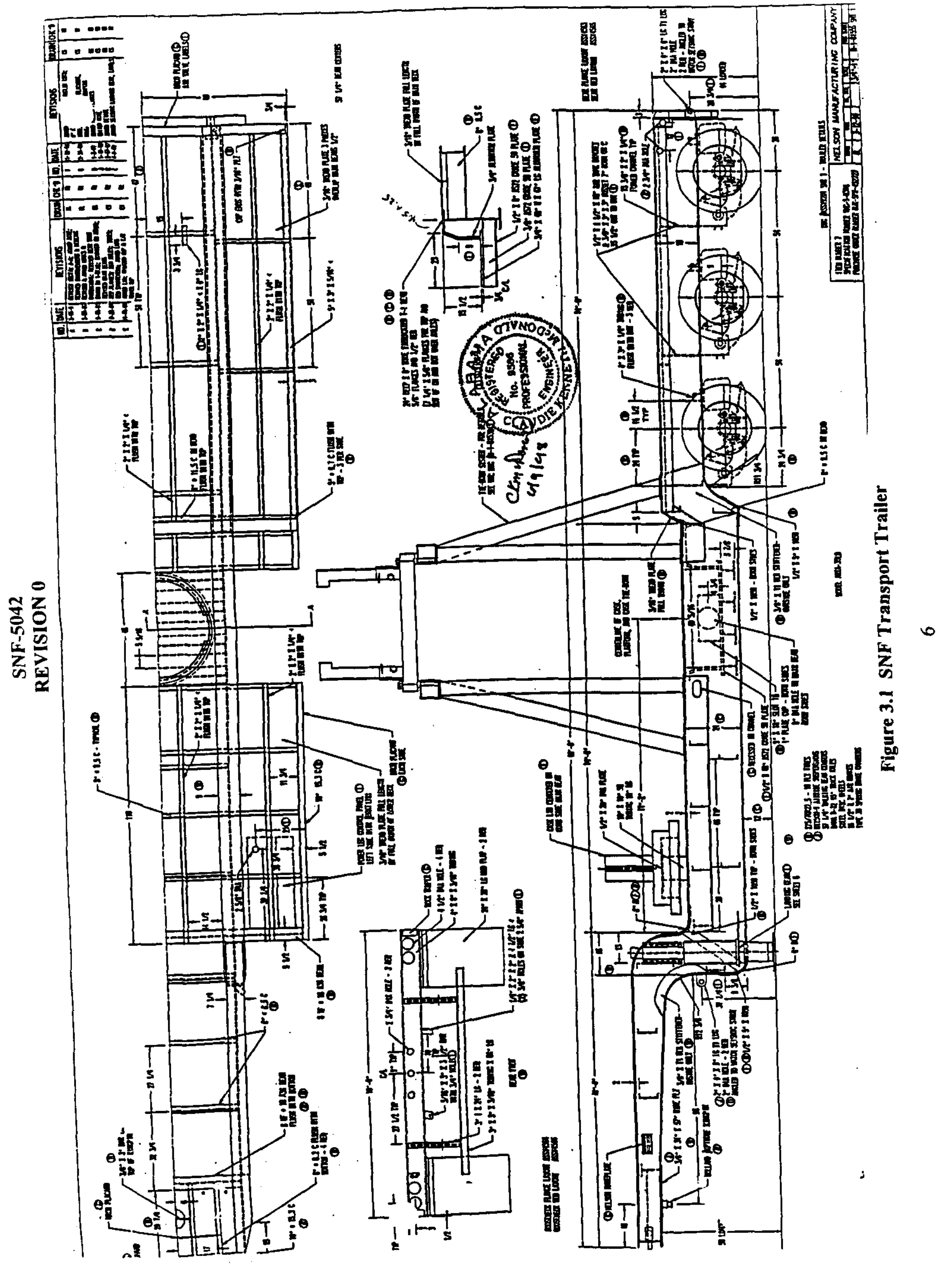




\section{SNF-5042 \\ REVISION 0}

The weight distribution for the six-axle combination will be approximately $10,000 \mathrm{lb}$. on the steering axle, $37,250 \mathrm{lb}$. on the tractor drive axles, and $57,620 \mathrm{lb}$. on the trailer tri-axle assembly (Chenault 1999). Using a footprint of 11.5 -in. by 6 -in. for the Bridgestone ${ }^{1}$ R294 tires currently on the trailer gives a uniform wheel pressure of $70 \mathrm{psi}$. The 11.5-in. loaded width is taken from Brisbin (1997), and the 6-in. length is from field measurements.

\subsection{Routing, Access Control, and Speed Limitations}

The cask is authorized for onsite exclusive-use transfer only. The first transfer leg consists of less than 0.5 miles between either the $\mathrm{K}$ East or $\mathrm{K}$ West Basin and the CVDF. The second leg consists of an 8-mile route following Route 1 out of the $100 \mathrm{~K}$ Area, then proceeding on Route $4 \mathrm{~N}$ to the CSB. The proposed transporter routing is shown in Figures 3.2, 3.3, and 3.4 the transporter must negotiate the proposed route(s) at speeds not to exceed $40 \mathrm{mph}$. (Kee 1995). Based on the number of assemblies and elements at the K Basins, approximately 400 total shipments are estimated (Chenault 1999).

Based on a field walkdown and document review, the road surface conditions and crosssection for the transport route are as identified in Table 3.1.

Table 3.1. Road Surface Conditions and Cross-Sections for the SNF Transport Route

\begin{tabular}{|l|l|l|l|l|}
\hline \multicolumn{1}{|c|}{ Portion of Route } & Surface Condition & \multicolumn{1}{|c|}{$\begin{array}{c}\text { Asphalt Concrete } \\
\text { Pavement (In) }\end{array}$} & $\begin{array}{c}\text { Top (Leveling) } \\
\text { Course (In) }\end{array}$ & \multicolumn{1}{|c|}{ Case Course (In) } \\
\hline 100 K AREA & Avg. to Poor & 2 & 2 & 6 \\
\hline CVDF Entrance & New & 3 & 4 & 4 \\
\hline 100 K to Rt. 1 & Avg. to Poor & 2 & 2 & 6 \\
\hline Rt. 1 & Avg. to Poor & Unknown & Unknown & Unknown \\
\hline Rt. 4S/4N & New overlay & Unknown & Unknown & Unknown \\
\hline Rt. 4S to CSB & Good & Good & N/A & 8 \\
\hline
\end{tabular}

The original construction documents could not be found for those conditions identified as "unknown."

\subsection{Identification of Underground Structures and Utilities}

The locations of the underground structures and utilities that will be traversed are given in Table 2.1. This table also gives the soil overburden depth and associated dead loads and the transporter live loads for each location.

\footnotetext{
'Bridgestone is a registered trademark of the Bridgestone Corporation, Nashville, Tennessee.
} 
REVISION 0

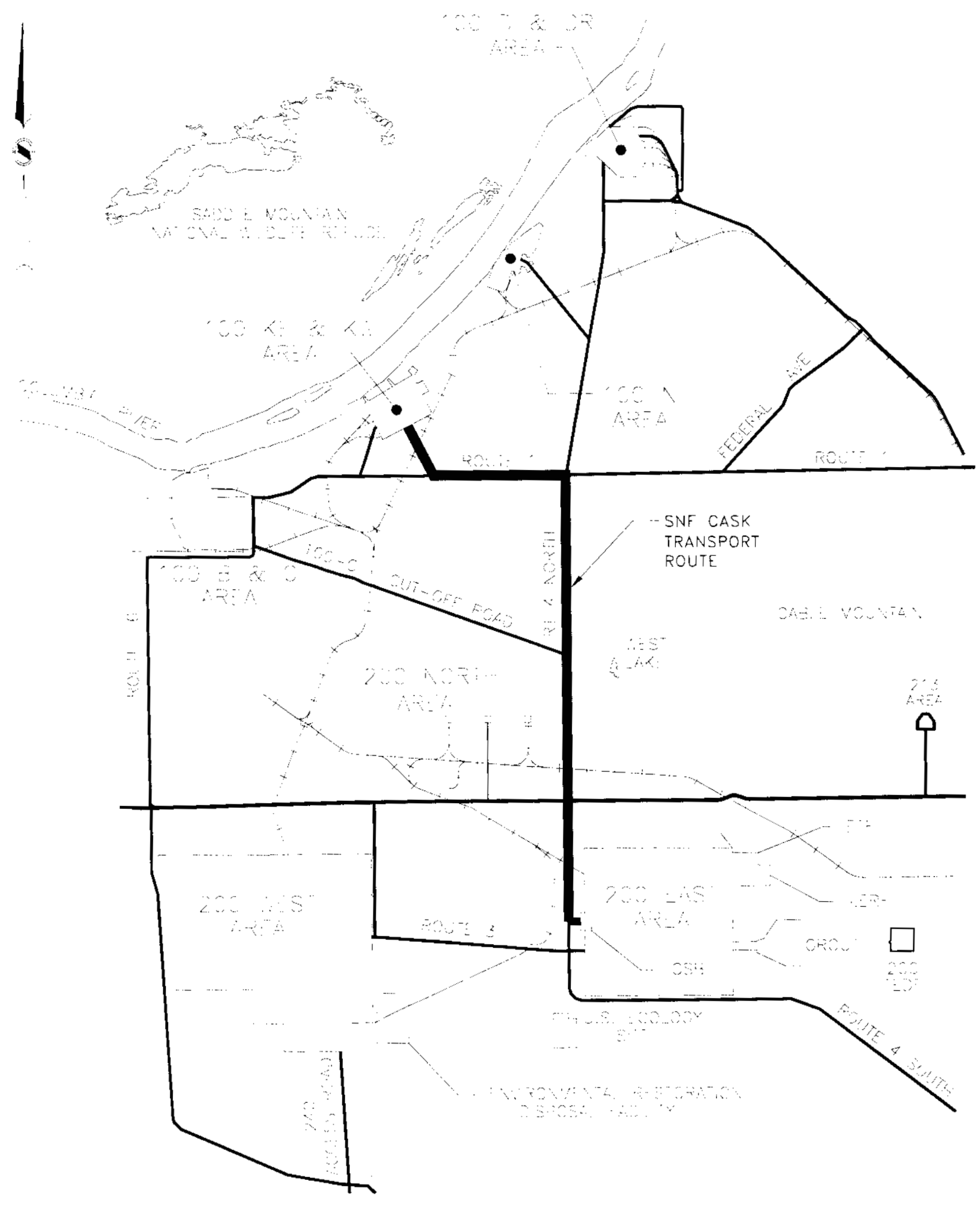

Figure 3.2. SNF Cask Transport Route 


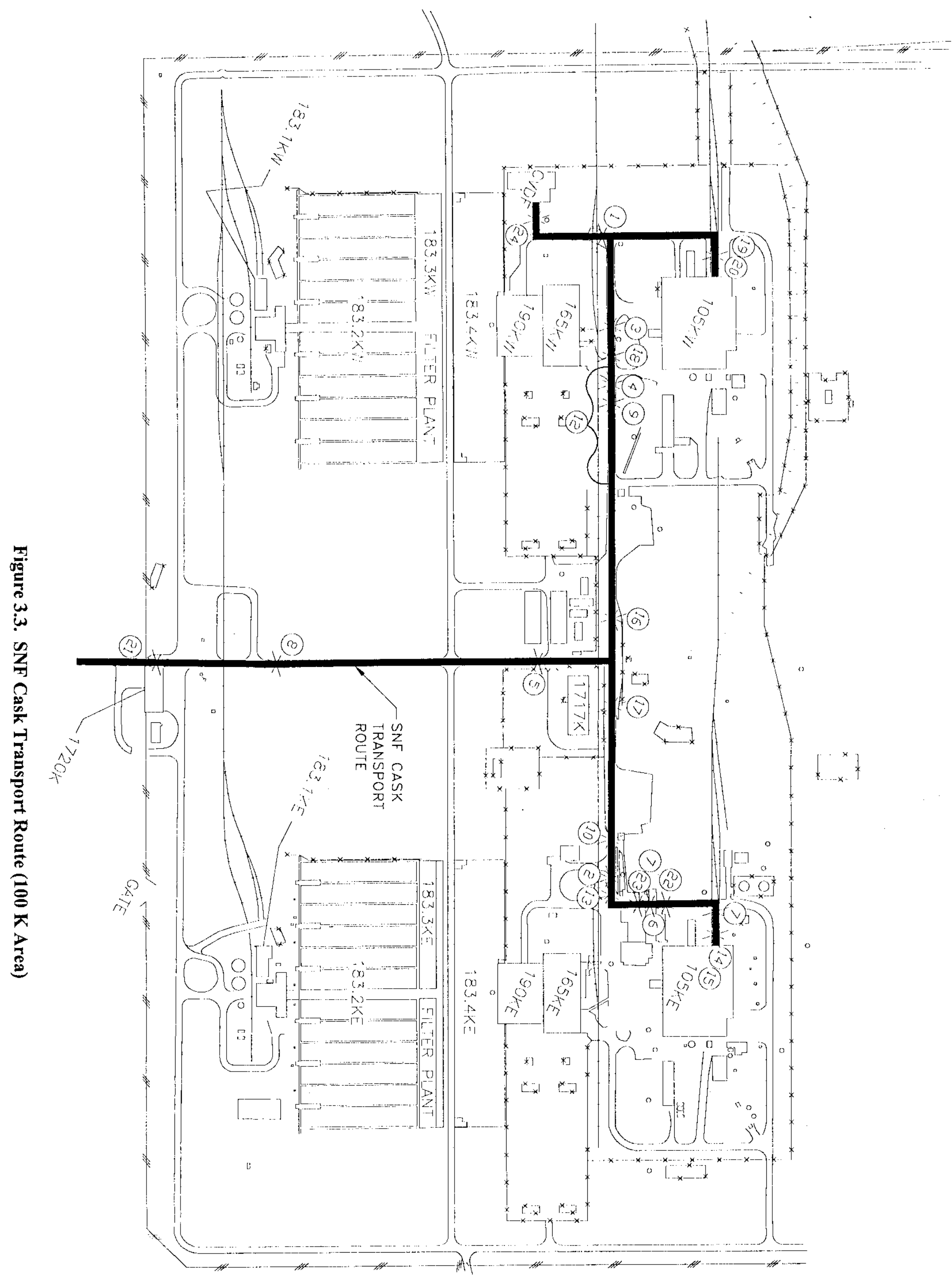


SNF-5042

REVISION 0

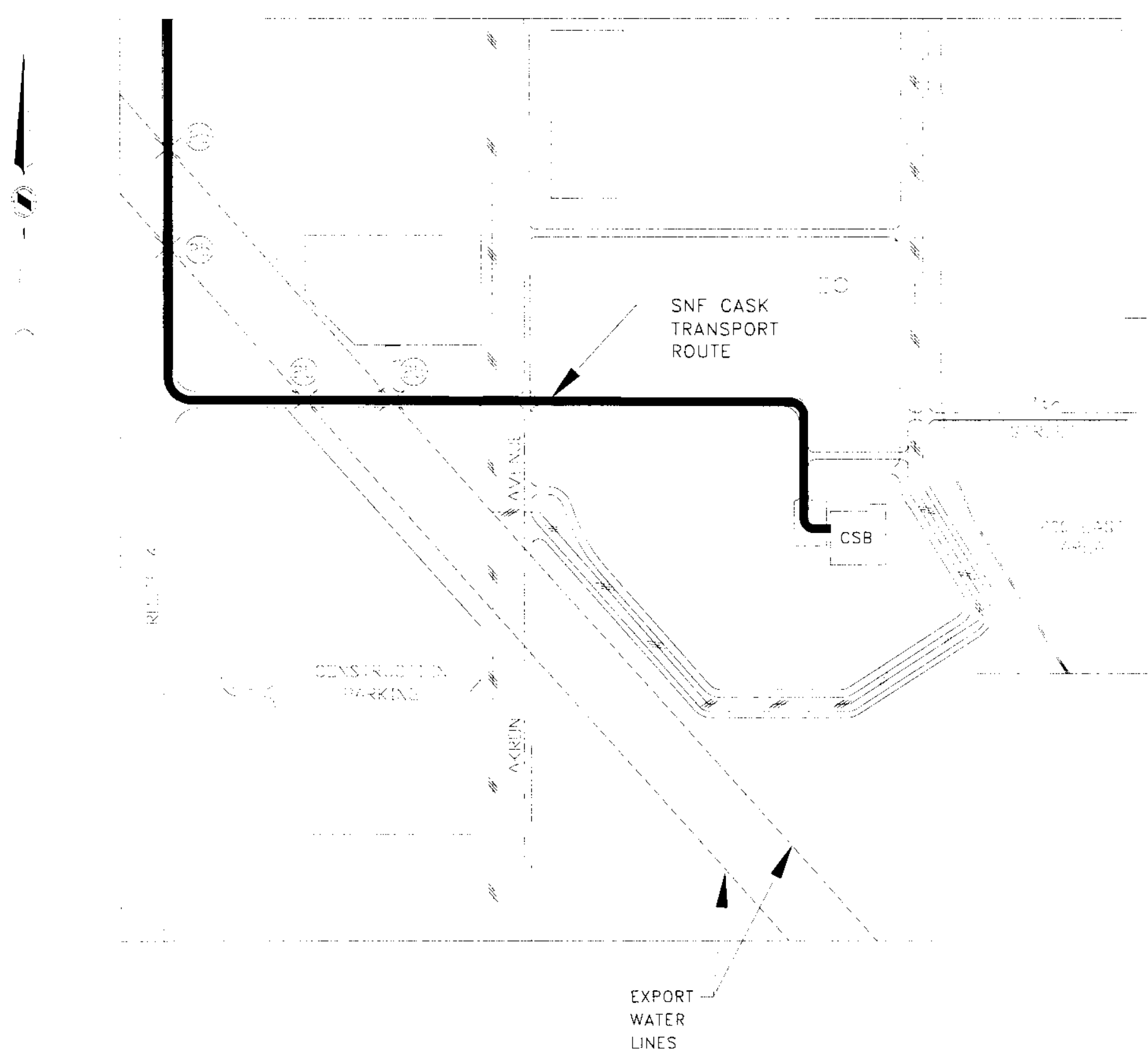

Figure 3.4. SNF Cask Transport Route (CSB) 


\section{SNF-5042 \\ REVISION 0}

Equation:

The soil dead loads for the underground utilities were calculated using the Marston

$\mathrm{W}_{\mathrm{c}}=\mathrm{C}_{\mathrm{d}} \mathrm{W} \mathrm{B}_{\mathrm{d}}^{2}$ length)

Where $\mathrm{W}_{\mathrm{c}}=$ the vertical external load on a closed conduit due to fill materials $(\mathrm{lb} . / \mathrm{ft}$ of

$\mathrm{C}_{\mathrm{d}}=$ the load calculation coefficient for conduits completely buried in ditches

$\mathrm{w}=$ the unit weight (density) of fill materials $\left(\mathrm{lb} . / \mathrm{ft}^{3}\right)$

$\mathrm{B}_{\mathrm{d}}=$ the width of the ditch at the top of the conduit (ft)

The analysis used a density of $110 \mathrm{lb} . / \mathrm{ft}^{3}$ for the overburden soil. This is based on data taken from various soils reports prepared for the 100 and 200 Areas of the Hanford Site. The trench width was assumed to be 18-in. for pipes up to 12-in. in diameter. For pipes over 12-in. in diameter, the trench width was assumed to be the diameter plus $2 . \mathrm{ft}$.

The live loads superimposed on the underground utilities by the transport trailer were determined using the "Percentages of Wheel Loads" table from the Clay Pipe Engineering Manual (NCPI 1995). The maximum load occurs when the trailer tri-axle is directly over the utility. The 57,620-lb. load is assumed to be evenly distributed over the three axles, giving an axle load of 19,206 lb. or a load of $9603 \mathrm{lb}$. at each set of dual wheels. Each of the five adjacent sets of dual wheels will also impose a load on the buried utilities. These will vary based on the size and depth of the utility, but will typically be about 10 percent of each adjacent wheel load, which would add another 50 percent, or $4,802 \mathrm{lb}$. for a total applied load of $14,405 \mathrm{lb}$. This load is then multiplied by the percentage taken from the table to determine the load imposed on the utility. It should be noted that the magnitude of the live load superimposed on the underground utilities decreases considerably as the soil overburden depth increases.

For the reinforced concrete tunnels, the trailer tri-axle weight of $57,620 \mathrm{lb}$. is also assumed to be evenly distributed over the three axles, giving a load of $9,603 \mathrm{lb}$. at each set of dual wheels or 4,802 lb. per wheel. The tire contact area was calculated to be 11.5 -in. $\times 6$-in. $=$ $71.4 \mathrm{in}^{2}$., which gives a uniform wheel pressure of $70 \mathrm{psi}$.

Impact loads will be generated by the movement of the transporter. These impact loads would normally be approximately 25 percent of the live load. However, the impact loads can be significantly reduced by regulating the speed of the transporter $(10 \mathrm{mph}$ or less within $100 \mathrm{~K}$ Area) and maintaining a relatively smooth roadway surface. By using these administrative controls, the impact loads can essentially be eliminated. Therefore, they are not considered in this evaluation, with the exception of the $\mathrm{KE}$ to $\mathrm{KW}$ crosstie tunnel location. Due to its importance and minimal depth, a 25 percent impact factor was considered (see Appendix A). 


\section{REVISION 0}

\subsection{ASSUMPTIONS AND UNCERTAINTIES}

This report considered all known utilities that will be traversed by the CTS transport trailer, some of which may not be currently in use.

As can be seen in Table 3.1, the soil overburden could not be determined for eight locations. The largest of these lines has a diameter of 12-in. If it was assumed that a 12-in. pipe had a soil overburden of $2 \mathrm{ft}$, the percentage of the transport trailer load superimposed on the pipe would be 6 percent or $922 \mathrm{lb}$./ff. Since most of these lines are much smaller that 12-in., and are most likely at least 3 to $4 \mathrm{ft}$ deep, the actual live load imposed is more in the range of 1 to 2 percent, which, as stated in the summary section, is insignificant when compared to the soil dead load already imposed on the pipe.

Since there are no longer any facilities at $100 \mathrm{~K}$ using oil or gas, it is assumed that the two 2-in. gas lines and the 12-in. oil line (location 23) are abandoned in place.

The reinforced concrete tunnels and sewers were assumed to be in good condition, however, this could not be confirmed. It is not within the scope of this task to determine their condition.

\subsection{REFERENCES}

AEC 1952, Contract No. AT(45-1)-624, Project No. CA-512-W, 100-K Water Plant Facilities, Structural Calculations Concrete Tunnel $165 \mathrm{~K}$ to $105 \mathrm{~K}$, U.S. Atomic Energy Commission, Hanford Operations Office, Richland, Washington.

Brisbin 1997, Design Analysis Report for the TN-WHC Cask and Transportation System, HNFSD-SNF-FDR-003, Rev. 0, Duke Engineering Services Hanford, Richland, Washington.

Chenault 1999, Cask Transportation System-System Design Description, SNF-3947, Rev. 0, Duke Engineering Services Hanford, Richland, Washington.

Islam 1995, Structural Evaluation for the $165 \mathrm{~K}$ Cross-Tie Tunnel, $100 \mathrm{~K}$ Area, WHC-SD-SNFFLE-001, Rev, 0, ICF Kaiser Hanford Company for Westinghouse Hanford Company, Richland, Washington.

Kee, A. T., 1995, Specification for SNF Path Forward Cask and Transportation System, WHCS-0396, Rev. 1, Westinghouse Hanford Company, Richland, Washington.

NCPI 1995, Clay Pipe Engineering Manual, National Clay Pipe Institute, Lake Geneva, Wisconsin. 
SNF-5042

REVISION 0

Appendix A

ARES Corporation Calculation No. 9904500.47-001, Revision 0

A-1

page 13 
SNF 5042

Rev 0

\section{CALCULATION/PROBLEM COVER SHEET}

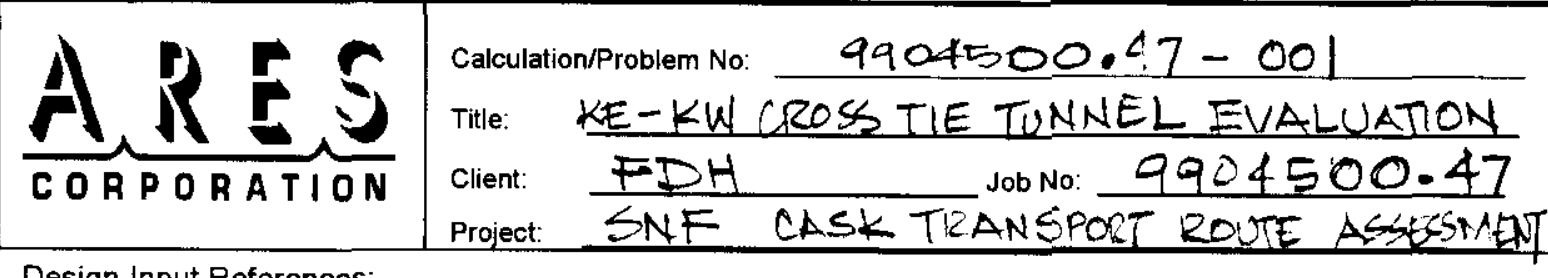
Design Input References:

PROVIL WITHW CALC.

Assumptions:

PROVIRED WITHINCALC

Method:

Hand calculations milg rokeks formulae

Remarks:

THE CALCULATOR DE EMHET THAT THE KE-KU! CHOC:-TIE TUNNEL IS STRUCTUKALLY ADEQULE TO WTISTAID CTS TRASBOT TRAILER lOADS.

\begin{tabular}{|c|c|c|c|}
\hline REV. NO. & REVISION & APPROVED & DATE \\
\hline 0 & ORIGIMAL ISSUE & 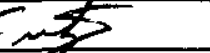 & 111049 \\
\hline & & 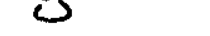 & \\
\hline & & & \\
\hline & & & \\
\hline & & & \\
\hline & & & \\
\hline
\end{tabular}


SNF-5042

Rov. 0

ARES

CALCULATION SHEET

Profect No: 9904500,47 CALC. No.: 001 Revision No.: 0

SHEET No: $2 / 7$

PREPAREDBY: A. GHo Se Date: $11 / 4 / 99$ RFVIEWEDBY: C.m conséman Date: lila/9?

OEJECTIVE: PERFORHA A GTHGTUAL EVALUATIOH of THE KI-KV! CLOSS-TIE TLMMEL FCL THE SNF CTS TRANEFOLT TKAILEK TR EETERMINE STRUCTURAL ADEqUACY.

EEFELLCEE: 1. US A.E.C. HANFORD WE:LE JWG NO.H-1-25:II,

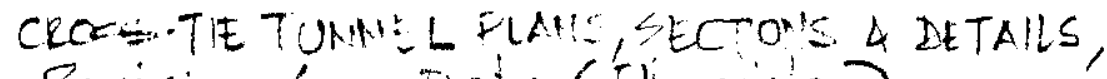
Revision 6, Dole (Ilecile)

2. WHC-SD-SNF'-FLE-OOl, ReV O, July 26.1995 , "Struetural Eval. For the $165 \mathrm{~K}$ Cross-Tie Tunnel, 100K Area," 3. HNF-SD-SNF- FDR-003, Rev 0, 1997, "Ie Gig Analysis Repart for the TN-WHC Cast and Transpotation Sinsten." 4. SNF-3947, ECV 0,1999," CTS System Disign Description" 5. ROREK'S FORMULAS FOR STRESS\& $\leq$ TRMNJ, GTHETION 6. ACI $318-95$

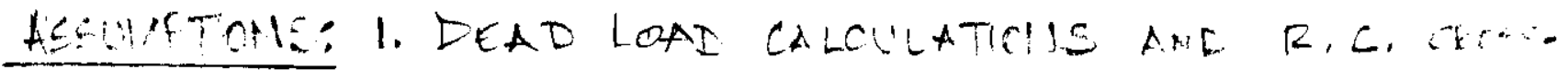

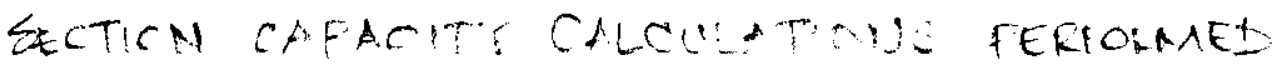
IN THE PREVIOUS OT. E A. LA ION (REF, 2)

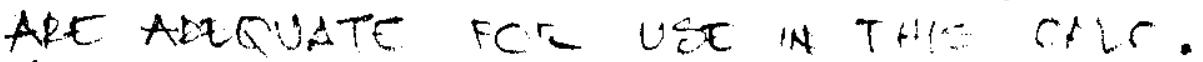

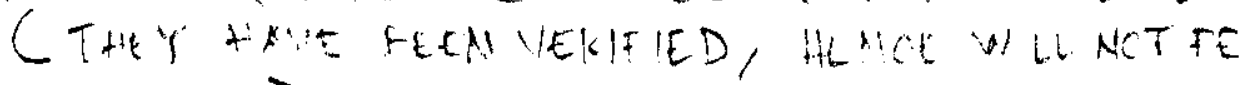
RETEITID

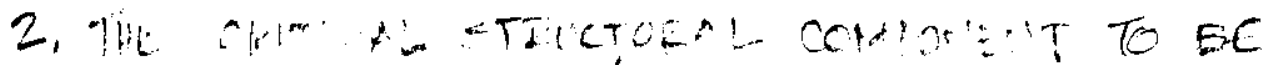

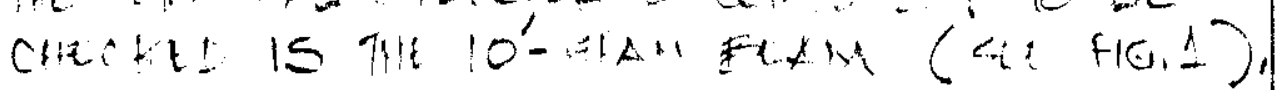

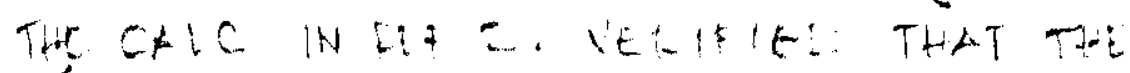

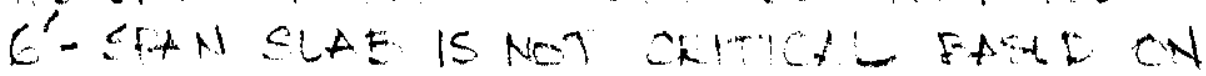

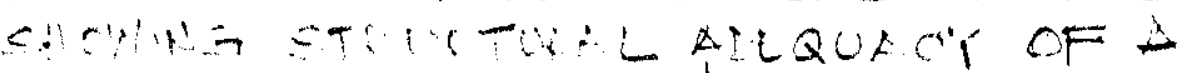

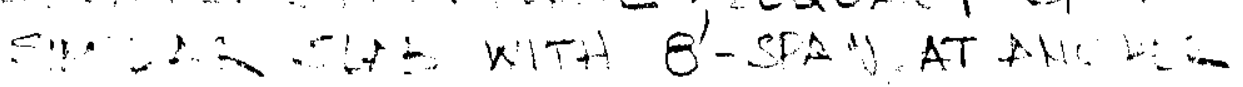
LE t TICP,

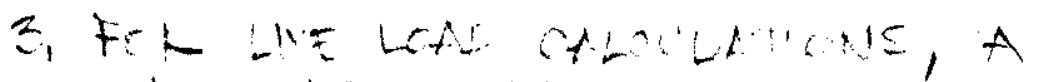

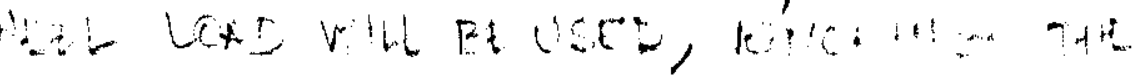

Pacy 15 
SNF 5042

Rsu 0

ARES

CALCULATION SHEET

Profect No: 9 an 4500.47 Calc. No.: Dol Revision No:: 0

SHeEr No.: $3 / 7$

Prepared By: A, Gite Date: $1 / 4 / 99$ ReVIFWIDBY: C.m. ConsELman Date: $11 / 9 / 20$

$$
\begin{aligned}
& \frac{A \operatorname{sen} \theta 010:}{(\cos )} \equiv(4)
\end{aligned}
$$

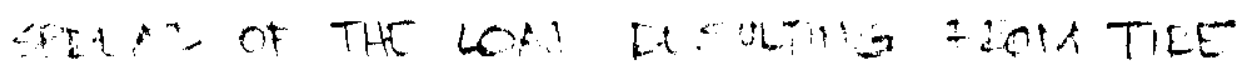

$$
\begin{aligned}
& \text { CCAH ST AKEA, NHE }
\end{aligned}
$$

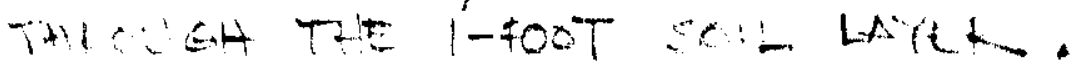

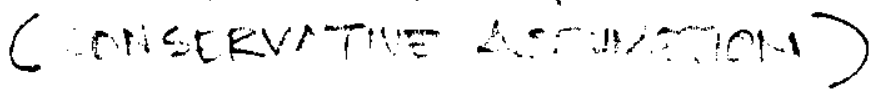

4. TEK HAUNCH IN THE 10-FT SERE EEPL WILL

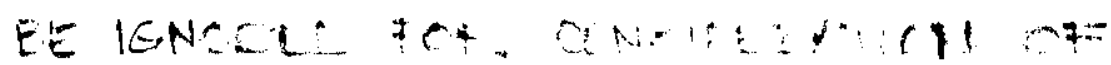
ELASTC FRIETES OF "HE BERTA, HE. A UNFORY ELASTC ELAMIE ANLLYSED,

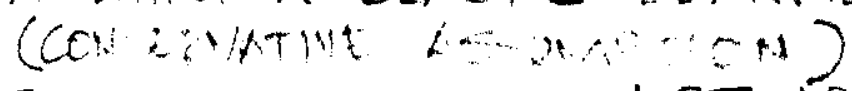

5. IMPA ? FACTOK OF 1.25 APPLIED to lIVE LOADS.

FG 1: CROS:-TE TUNNEL LAYOCT PLAN (FVOM REF. 1)

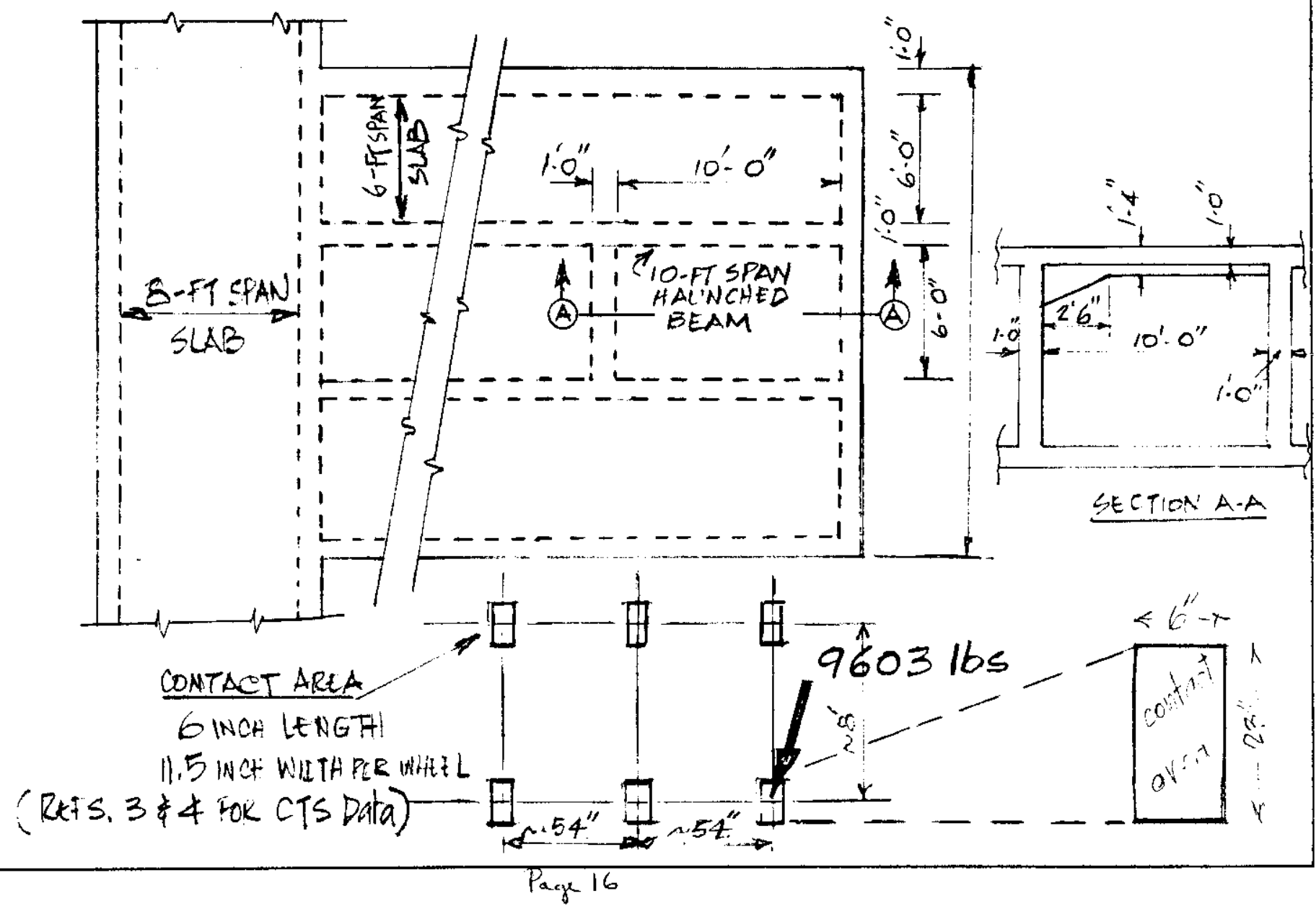


SN -5042

Rev. 0

ARES

CALCULATION

SHEET

Project No.: 9904500,47 Call. No.: 001 Revision No: 0

SHEET No: 47

Prepared By: $\AA_{1}$ GHOCE

DATE: $11 / 4 / 99$

REVIEWED BY:

.

ANALYSIS OF $10, \mathrm{fT}$ SPAN BEAM.

$$
\begin{aligned}
& \text { Loft combination } \rightarrow 1.4(D L)+1.7(L L) \\
& 1.4(I L)=187.8^{\#} / \text { in }=W(\operatorname{Ret} 2, p A-21)^{2} \quad l=120^{\prime \prime} \\
& 1.7(\mathrm{LL})=1.7 \times 9,603=16335 b_{1}=\mathrm{W} .
\end{aligned}
$$

Ref 5: Rook' Formulas for Stress and strain, oration. TALL 3 . PP $100-10 \mathrm{~s}$

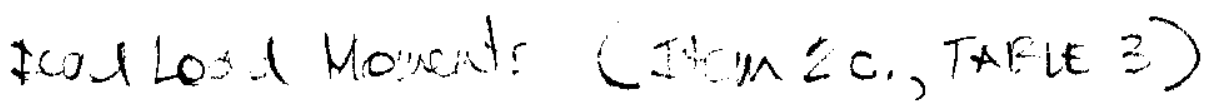

$$
\begin{aligned}
& \text { Nah } H^{+}=\frac{9 w l^{2}}{125}=\frac{9 \times 187.8 \times(1.0)^{-}}{125} \\
& =190,145 \$-\text { in } \\
& \text { Max } M^{-}=\frac{w l^{2}}{8}=328,040 \# \text { in }
\end{aligned}
$$

SINGLE AXLE IN STAN

Live Load Moments (HCMN 1C, TAEUE $\equiv$ )

$$
M \circ \times M^{+}=0.174 W l=040,866 \mathrm{H}-\mathrm{in}
$$

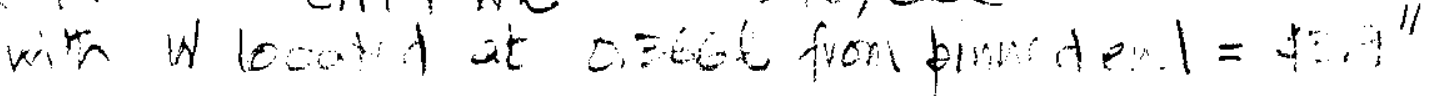

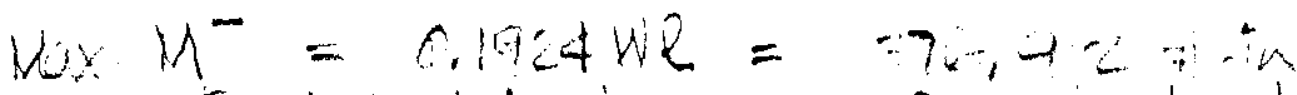
with wi lowed at $0.577 \mathrm{~h}$ from pine $21 \mathrm{~d}=63.5 \%$

en , Fine

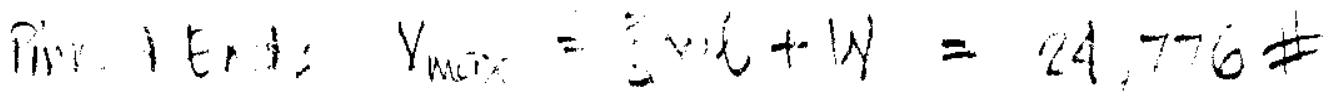

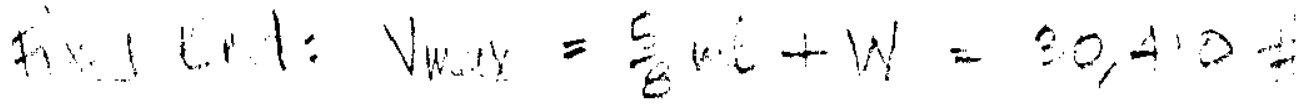

Pase 17 
$S N F-5042$

RoN 0 .

$\underset{\text { corporation }}{R \mathbf{E}}$

CALCULATION SHEET

Project No:: 9904500.47 Talc. No.: 0.91 Revision No.: 0

SheEt No: $5 / 7$

Prepared BY: A. $6.40=$

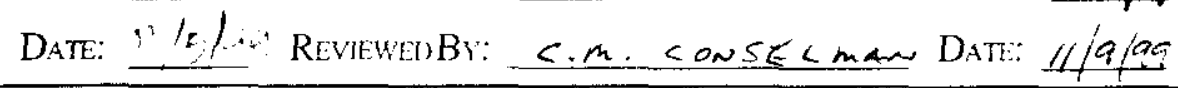

HO AXES IN SIXIDI

Wive Load M

For W:

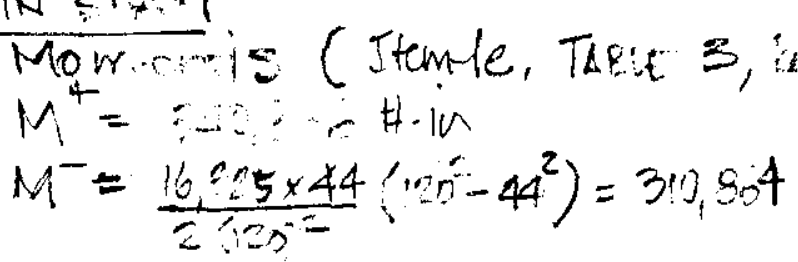

For Viz:

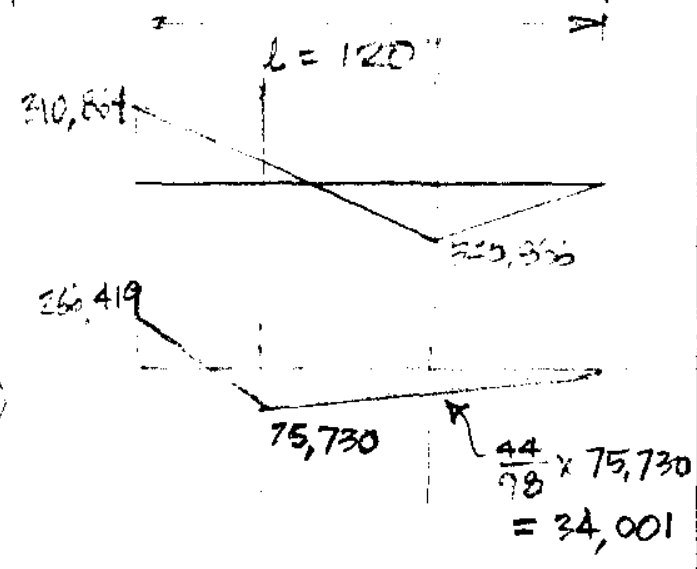

$$
\begin{aligned}
& a=54+44=\cdots \\
& l=18 \mathrm{~m} \\
& M^{\top}=\frac{b^{3}}{2 l^{3}}(u-a)^{2}(c+a) \\
& =10=2 \times 98(25) \\
& =7 \pm 730 \#-\text { in }
\end{aligned}
$$

$\therefore F_{54}^{W} W^{W}{ }^{W}=$

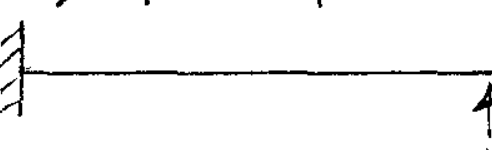

$$
x
$$$$
\begin{aligned}
M & =\frac{1 a}{5}\left(l^{2}-a^{2}\right) \\
& =10=5 \times 98 \cdot\left(120^{2}-95^{2}\right) \\
& =(100)^{2}
\end{aligned}
$$$$
=26 \cdots, 4: 9 \text { in }
$$

$$
\begin{aligned}
& M \% N^{+}=340,866+34,001=374,867 \# \cdot \text {. } \\
& M_{\lambda \times M^{-}}=310,864+264,419=577,285 \text { H. in }
\end{aligned}
$$

THEE PULS N SEAS

Live Le a: Mounds

$$
\begin{aligned}
& \text { For } V_{1}: a=6 \quad M=\frac{16=0 \times 6}{2 x}(114)^{2}(24090,601
\end{aligned}
$$

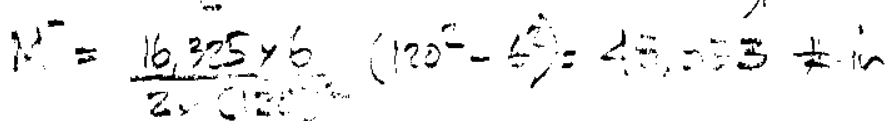

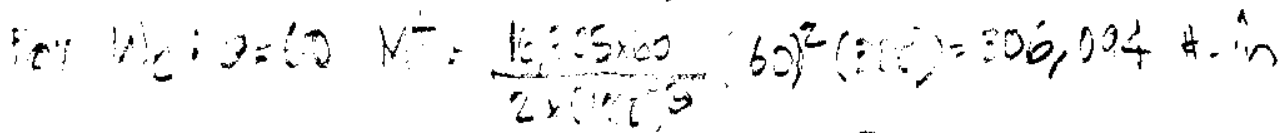

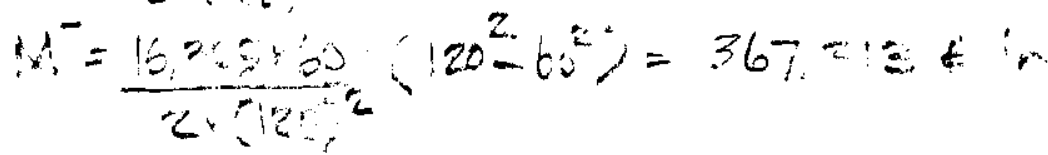

Page 18 
SNF-5042

Row. 0

CALCULATION

ARES

SHEET

Project No.: 9904500.47 Talc. No.: COl Revision No.: 0

SheET No: $6 / 7$

Prepared By: $\$$ G HOSE

DATE: $11 / 5 / 99$ ReVIEWEDBY: cm consELmAN DATE: $1 / 9 / 99$

ThEE AXLES IN SPAY (Cent))

$$
\begin{aligned}
& \text { For } W_{3}: a=114 M^{+}=\frac{16325 \times 114}{2 \times(120)^{3}}(6)^{2}(35)=6,863 \# \text { - in } \\
& M^{-}=\frac{16,325 \times 114}{2 \times(120)^{2}}\left(120^{2}-114^{2}\right)=0,0,726 \#-i n \\
& \text { Mat } M^{+}=\left[(90610+48853) \frac{60}{14}-48,853\right] \div\left[306,0977+\left[0,803 \times \frac{60}{14}\right]\right.
\end{aligned}
$$

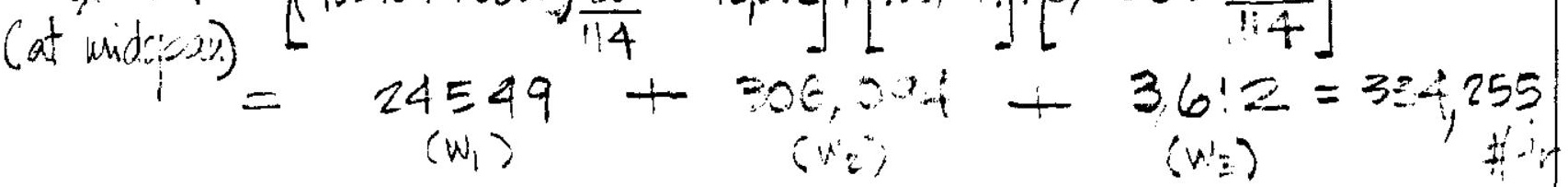

$$
\begin{aligned}
& \operatorname{Max} M^{-}=48,50 \equiv+367,3: \equiv+90,726=506,890 \\
& \left.+(1-108)^{2}(22+108)\right] \\
& =16,3.5+16,325 \frac{(120-54)^{2}(294)}{2(120)^{3}}+16,325 \frac{(120-108)^{2}(349)}{.(20)} \\
& =16,325+6,049+237 \mathrm{w}=22,611165 .
\end{aligned}
$$

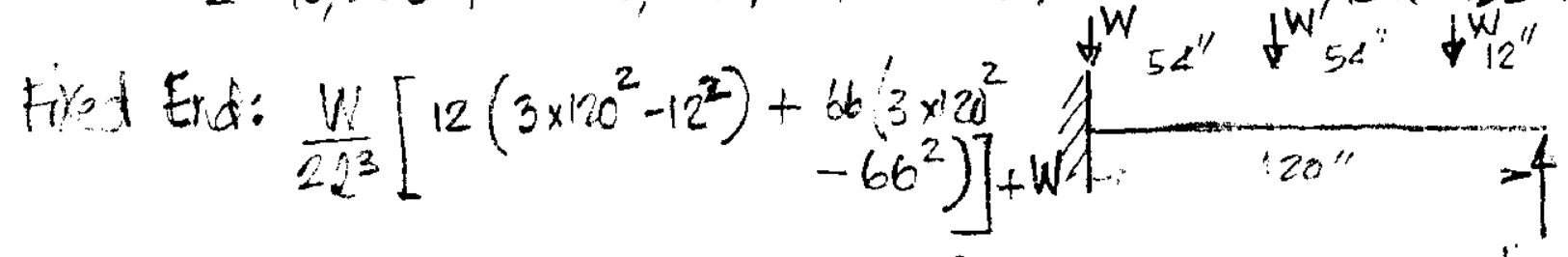

$$
=2441+12,110+16,315=3,376 \%
$$

$$
\begin{aligned}
V_{\text {wy }} & =5 \cdot 2+1.25 \times 30,876 \quad \text { C LL Impact Factor }=1,25 \\
& =1400-38,595=52,680 \mathrm{~b} .
\end{aligned}
$$

Page 19 
SN 5042

Re vo

ARES

CALCULATION

SHEET

Project No: 9904500,47 Call. No.: 001 Revision No: 0

SHEET No: $7 / 7$

PREPARED BY: $\quad t(-n H n: "$

Date: $1 / 4 / 99$

ReViEWED BY:

DATE: $11 / 2 / 29$

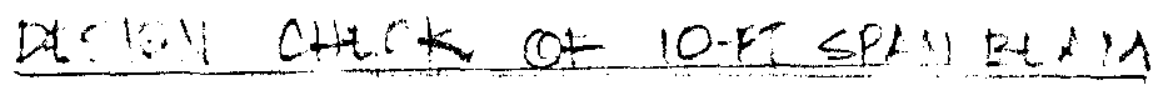

(foul Kef 2, pizz for $M_{u}^{+}, p$. e 10 for $M_{u}^{-}$)

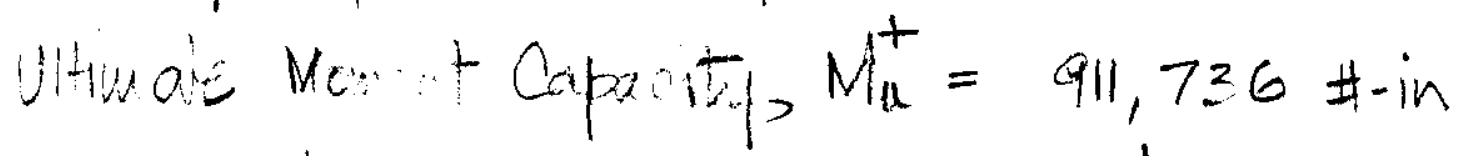

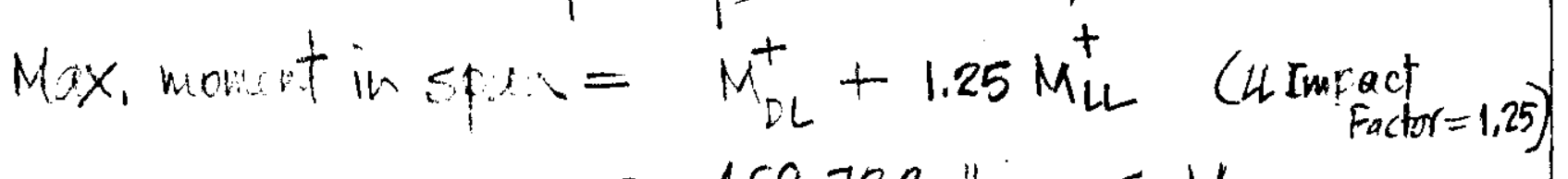

$=658,7327_{-14}<\mathrm{Mu}$

Hwan Moment Capacity, $M_{U}^{-}=2,512,674$ \#-in

Max. support moment $=M D L+1,25 M_{L L}$ (LL Impact

$$
=1,059,644 \# \text {-in }<M \bar{u}
$$

Mamet capacity is ok.

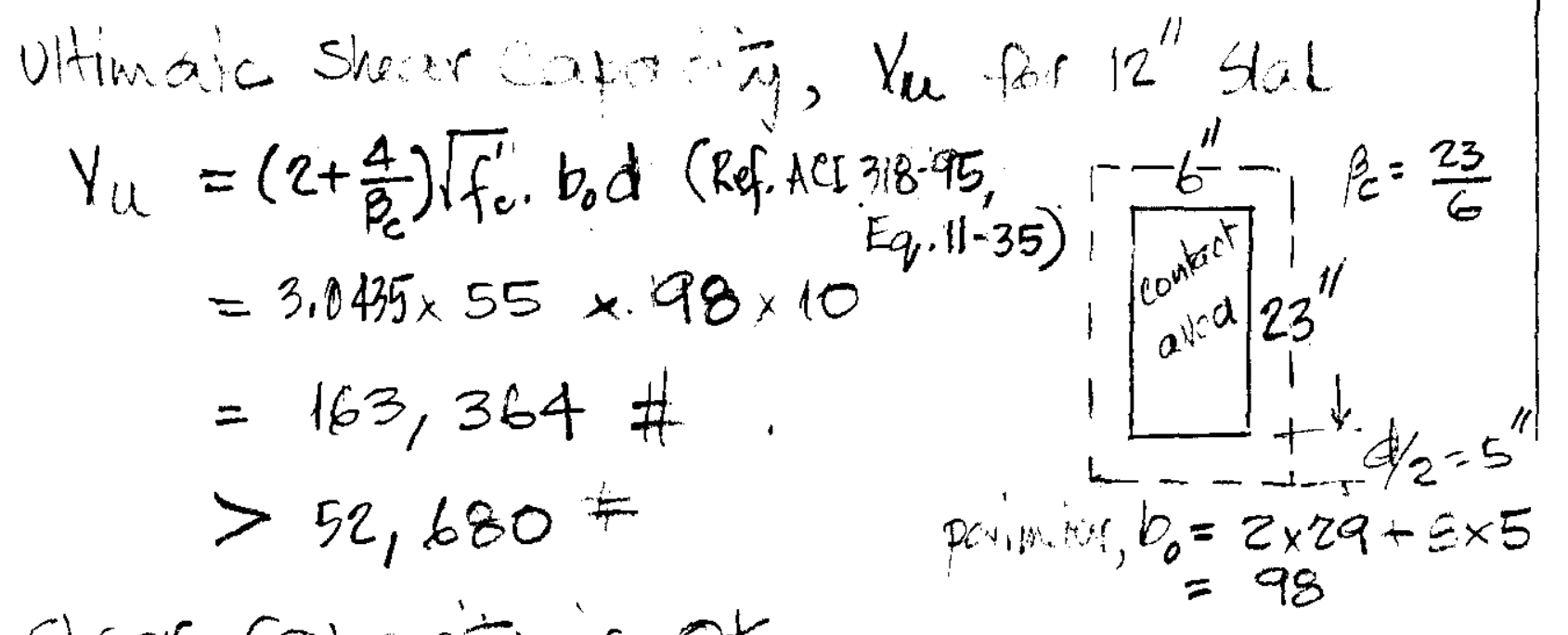

Shear cafacin is ok.

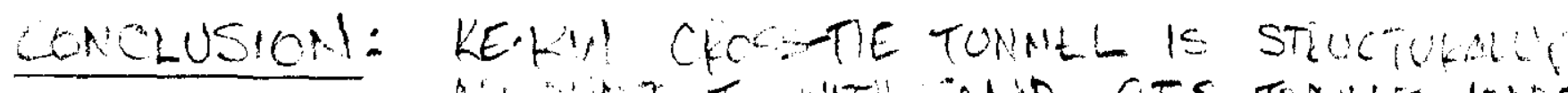
Fin

Page 20. 